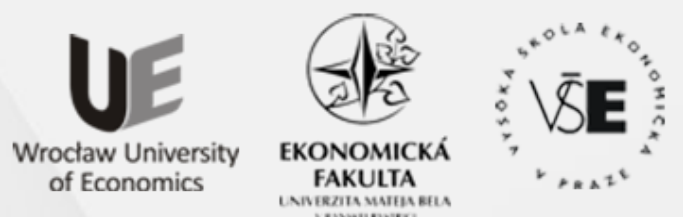

Conference Proceedings

Full TeXT PAPERS

edited by

Zofia Rusnak and Beata Zmyślona

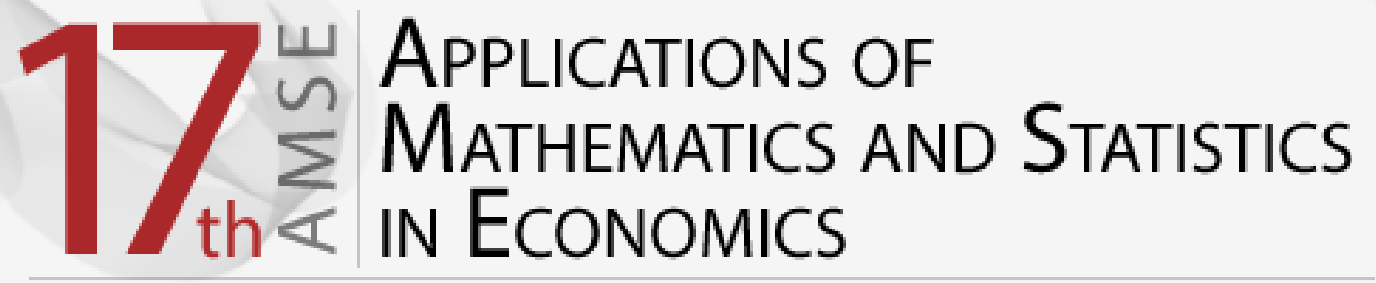

International Scientific Conference | Poland • 27-31 August 2014 
Scientific Committee

Richard Hindls, Stanislava Hronová, Rudolf Zimka, Walenty Ostasiewicz, Emília Zimková, Zofia Rusnak, Martin Bod'a

Organizing Committee

Beata Zmyślona, Cyprian Kozyra, Grzegorz Rogoziński, Kristýna Vltavská

\section{Reviewers}

Milan Bašta, Diana Bílková, Martin Bod'a, Joanna Dębicka, Tomáš Fiala, Jakub Fischer, Stanisław Heilpern, Karel Helman, Lenka Hudrlíková, Miroslav Hužvár, Nikola Kaspř́ková, Alena Kaščáková, Kamil Kladívko, Jindřich Klůfa, Pavol Král', Katarzyna Kuziak, Jana Langhamrová, Ivana Malá, Tomáš Marcinko, Luboš Marek, Miloš Maryška, Petr Mazouch, Zofia Mielecka-Kubień, Witold Miszczak, Petr Musil, Gabriela Nedelová, Walenty Ostasiewicz, Iva Pecáková, Viera Roháčová, Zofia Rusnak, Mária Stachová, Jana Špirková, Šárka Šustová, Jana Tepperová, Vladimír Úradníček, Kristýna Vltavská, Michal Vrabec, Dariusz Wawrzyniak, Henryk Zawadzki, Jaroslav Zbranek, Tomáš Zeithamer, Martin Zelený, Jan Zeman, Rudolf Zimka, Emília Zimková, Pavel Zimmermann, David Žižka

Layout

Martin Bod'a, Beata Zmyślona, Grzegorz Rogoziński

Front page design

Grzegorz Rogoziński

CD cover design

Beata Dębska

Articles published in the form submitted by the authors

All rights reserved. No part of this book may be reproduced in any form or in any means without the prior permission in writing of the Publisher

(C) Copyright by Wrocław University of Economics Wrocław 2014

ISBN 978-83-7695-421-9

Wydawnictwo Uniwersytetu Ekonomicznego we Wrocławiu

53-345 Wrocław, ul. Komandorska 118/120 www.ue.wroc.pl

Sprzedaż książek tel./fax 71 36-80-602

e-mail: econbook@ue.wroc.pl www.ksiegarnia.ue.wroc.pl 


\section{Contents}

Foreword

Diana Bílková: TL-Moments: Analogy of Classical L-Moments

Dagmar Blatná: Application of Robust Regression in the Analysis of Internet Access in European Countries

Martin Bod’a, Mária Kanderová: Rebalancing Issues in Tracking Error Variance Minimization

Martin Bod'a, Viera Roháčová: Application of Six Sigma Ideas to Timing Decisions at Financial Markets

Anton Dekrét, Rudolf Zimka: On the Price Hartwick's Task and Its Inverse in a Dynamic Model of an Economy with Exhaustible Resources

Joanna Dębicka, Agnieszka Marciniuk: Comparison of Reverse Annuity Contract and Reverse Mortgage on the Polish Market.

Petra Dotlačilová, Jitka Langhamrová: The Influence of Mortality Models for the Expected Future Life-time of Older People

Marek Ďurica, Lucia Švábová: Delta and Gamma for Chooser Options.

Vlastimil Farkašovský: New Concept of Pension Funds Performance Evaluation

Albert Gardon: The Normality of Weekly Relative Changes of the Freight Rate in Container Shipping.

Mária Grausová, Miroslav Hužvár, Jana Štrangfeldová: Healthcare Systems Efficiency in the Visegrád Group.

Stanisław Heilpern: Multiple Life Insurance - Pension Calculation

Alena Kaščáková, Gabriela Nedelová: Changes in Slovak Households' Economy

Igor Kollár, Pavol Král', Peter Laco: Methodology for Assessing Website Improvement in Corporate Environment.

Maciej Kostrzewski: Some Method of Detecting the Jump Clustering Phenomenon in Financial Time Series.

Cyprian Kozyra, Beata Zmyślona, Katarzyna Madziarska: Complementary Objective and Subjective Measures of Hospital Services Quality...

Pavol Král', Mária Stachová, Lukáš Sobíšek: Utilization of Repeatedly Measured Financial Ratios in Corporate Financial Distress Prediction in Slovakia

Ivana Malá: The Use of Finite Mixture Model for Describing Differences in Unemployment Duration

Lukáš Malec: Studying Economics and Tourism Industry Relations by Smooth Partial Least Squares Method Depending on Parameter. 
Tomáš Marcinko: Consequences of Assumption Violations Regarding Classical Location Tests.

Edyta Mazurek: The Income Tax Progression Depending on Social Insurance Contribution in Poland.

Petr Musil, Jana Kramulová, Jan Zeman: Regional Consumption Expenditures: An Important Starting Point for Regional Input-output Tables.

Katarzyna Ostasiewicz, Walenty Ostasiewicz: Good Life: From Political to Human Economy

Anna Sączewska-Piotrowska: Analysis of Poverty Transitions in Poland Using Multilevel Discrete-Time Event History Models

Martina Šimková, Petra Švarcová: Disadvantaged University Students in the Czech Republic.

Michal Široký: The Use of Short-term Business Statistics for Quarterly GDP Flash Estimates in the Czech Republic

Zdeněk Šulc, Hana Řezanková: Evaluation of Recent Similarity Measures for Categorical Data.

Lucia Švábová, Marek Ďurica: The Relationship Between the Finite Difference Method and Trinomial Trees

Kristýna Vltavská, Jaroslav Sixta: The Estimation of Final Consumption Expenditures

Lenka Vraná: Business Cycle Analysis: Tracking Turning Points

Janusz Wywiał: On Bayesian Testing in Auditing

Emília Zimková: Window Analysis of Supper-efficiency Change: Case of the Slovak Banking System ....

Beata Zmyślona: Statistical Modelling of the Impact of Diabetes on the Risk of Hospitalization 


\title{
BUSINESS CYCLE ANALYSIS: TRACKING TURNING POINTS
}

\author{
LENKA VRANÁ \\ University of Economics, Prague, Faculty of Informatics and Statistics, Department of Statistics and \\ Probability, W. Churchill Sq. 4, Prague 3, Czech Republic \\ email: lenka.vrana@vse.cz
}

\begin{abstract}
Composite indicators are recognized to be an eligible tool of the business cycle analysis, especially because they can be easily interpreted although they summarize multidimensional relationships between individual economic indicators.

Attempts of constructing the composite indicators for the Czech economy have been based mostly on the OECD methodology. This approach compares the cyclical component of the individual time series with the cycle of the reference time series (usually GDP or industrial production index) and selects only those with the strongest dependencies. The relationship evaluation should be based on the average lead or lag times between the turning points, cross correlations and number of extra and missing cycles. Usually only cross correlations are used in the Czech business cycle analyses as they are easy to compute. However, they should be used only in the combination with the other criteria.

This paper describes the problem of dating the business cycle which enables track and the proper analysis of the turning points. The classic non-parametric algorithm is illustrated with dating selected economic indicators and the results are compared with a simplified method that uses only the cross correlations.
\end{abstract}

Key words: dating business cycle, turning points, composite indicators, cycle measurement.

DOI: $10.15611 /$ amse.2014.17.30

\section{Introduction}

In recent years due to the economic slowdown the public attention was focused on the possibilities of forecasting the business cycle movements. One of the methods used for the cycle analysis is based on the study of composite indicators which combine several individual economic indicators and which should enable to monitor the state of business cycle better than just by analyzing the individual time series.

The construction of composite indicators usually follows methodology created by the Organization for Economic Co-operation and Development (OECD) or by the Conference Board. Most of the analyses of the Czech business cycle use OECD methodology which will be employed in this paper as well. For more information about the Conference Board methodology see Zarnowitz and Ozyildirim (2006) or Ozyildirim et al. (2010).

The OECD methodology (Gyomai and Guidetti, 2012) consists of five steps: 1. pre-selection phase, which is passed only by long time series of indicators that have justified economic relationship with the reference series, broad coverage of economic activity and high frequency of observations, 2. filtering phase, when the time series are seasonally adjusted and de-trended, 3. evaluation phase, when only the best individual indicators with the strongest relationship with the reference series are selected to be included in the composite 
indicator, 4. aggregation phase, when the composite indicators are created and 5. presentation of the results.

The authors of the Czech composite indicators usually simplify the evaluation phase of computational algorithm. OECD uses several methods how to evaluate the relationships between the time series: the average lead or lag times between the turning points, cross correlations and number of extra and missing cycles. Usually only cross correlations are used in the Czech business cycle analyses as they are easy to compute; see Czesaný and Jeřábková (2009) or Tkáčová (2012). However, it is recommended to use the cross correlations only in the combination with other criteria (Gyomai and Guidetti, 2012).

This paper will describe Bry-Boschan algorithm that enables the tracking and the analysis of the cycle turning points. It is one of the non-parametric methods, for different approaches how to date the cycle see Bruno and Otranto (2008). Bry-Boschan algorithm will be applied to three selected indicators (index of industrial production, import and composite confidence indicator). The results will be compared with the simplified approach that uses only the cross correlations.

\section{Bry-Boschan algorithm}

Not every peak or trough of the indicator is considered as the turning point. In 1946 Arthur Burns and Wesley Mitchell analyzed business cycles and laid the foundations of business cycle dating. The dating was executed manually and it required lots of personal judgment and therefore it wasn't quite objective.

Gerhard Bry and Charlotte Boschan introduced their algorithm for turning points detection in 1971. It was one of the first programmed approaches that were published and with the fast development of information technologies was than widely implemented. OECD and other organizations still use this algorithm with only slight changes. In the first proposal, Bry and Boschan used 12-month moving average, Spencer curve and short-term moving average of 3 to 6 month to detect the turning points. Nowadays none of these are necessary because some other techniques (like Hodrick-Prescott filter) are used to smooth the time series without shifting the turning points.

Bry-Boschan algorithm (Bry and Boschan, 1971) consists of 6 steps:

1. Identification of points higher (or lower) than 5 months on either side.

2. Enforcement of alternation of turns by selecting highest of multiple peaks (or lowest of multiple troughs).

3. Elimination of turns within 5 months of beginning and end of series.

4. Elimination of peaks (or troughs) at both ends of series which are lower (or higher) than values closer to end.

5. Enforcement of minimum cycle duration of 15 months by eliminating lower peaks and higher troughs of shorter cycles.

6. Elimination of phases whose duration is less than 5 months.

The algorithm also suggests the best practices for dealing with anomalous situations (e.g. double turns). Implementation of Bry-Boschan algorithm gave similar results as the manual analysis of the cycle and enabled to process the large datasets very quickly. 


\section{De-trending time series}

Bry-Boschan algorithm can be applied only to the indicators that have been seasonally adjusted and de-trended. Since December 2008 OECD has used Hodrick-Prescott filter to decompose the time series.

Hodrick-Prescott filter divides the series into two parts $\left(\tau_{t}\right.$ - trend component and $c_{t}$ - the cyclical component) and optimizes expression

$$
\min _{\tau_{t}}\left[\sum_{t}\left(y_{t}-\tau_{t}\right)^{2}+\lambda \sum_{t}\left(\tau_{t+1}-2 \tau_{t}+\tau_{t-1}\right)^{2}\right] .
$$

It minimizes the difference between the trend and the original series and smoothes the trend as much as possible at the same time. The $\lambda$ parameter prioritize the latter from the two contradictory goals - the higher the $\lambda$, the smoother the trend.

Hodrick-Prescott filter deals with the series as with the system of sinusoid and it keeps in the trend only those with low frequency (high wave length). According to OECD the business cycles last 10 years at maximum therefore the fluctuations with lower wave length should be kept in the cycle component. Ravn and Uhlig (2002) recommend to set the $\lambda$ parameter equal to 129600 to do so for monthly series. Nilsson and Gyomai (2011) confirm that HodrickPrescott filter gives clear and steady turning point signals when applied twice: first with high $\lambda$ to find the trend and then with low $\lambda$ to smooth the cycle component.

\section{Application of Bry-Boschan algorithm}

\subsection{Data}

Bry-Boschan algorithm will be illustrated with the cycle analysis of three selected economic indicators: index of industrial production (IIP), import and composite confidence indicator (CCI). Each of these time series is available from January 2002 to August 2012 on monthly basis and was seasonally adjusted by the Czech Statistical Office (see fig. 1).

These indicators were selected arbitrary not as the result of the pre-selection phase. The industrial production index was chosen because it shows strong co-movements with the GDP and (unlike GDP) is available monthly and published sooner. It will be used as the reference time series which means that the other two indicators will be compared to IIP. The import was selected because of its unclear link to the Czech business cycle. While Czesaný and Jeřábková (2009) classify it as one of the lagging indicators, it is included in the set of leading indicators by Tkáčová (2012). As the Czech economy is small and open, there could be significant relationship between the business cycle and the cycle component of the import. The composite confidence indicator (also known as economic sentiment indicator) is calculated as a weighted average of confidence indicators in industry, construction, trade, in selected services and of the consumer confidence indicator (Czech Statistical Office, 2012). Confidence indicators are very often included in the composite leading indicators. 


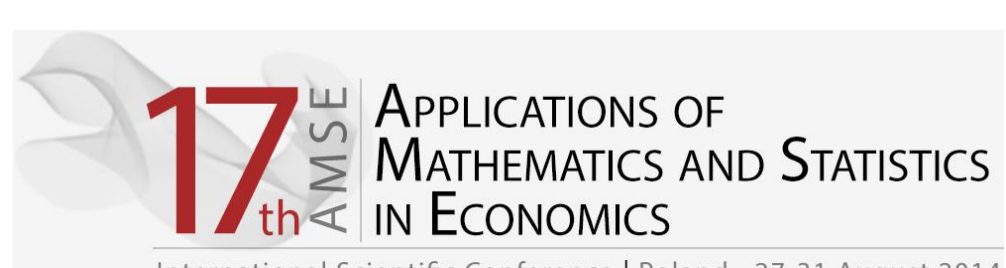

International Scientific Conference | Poland • 27-31 August 2014
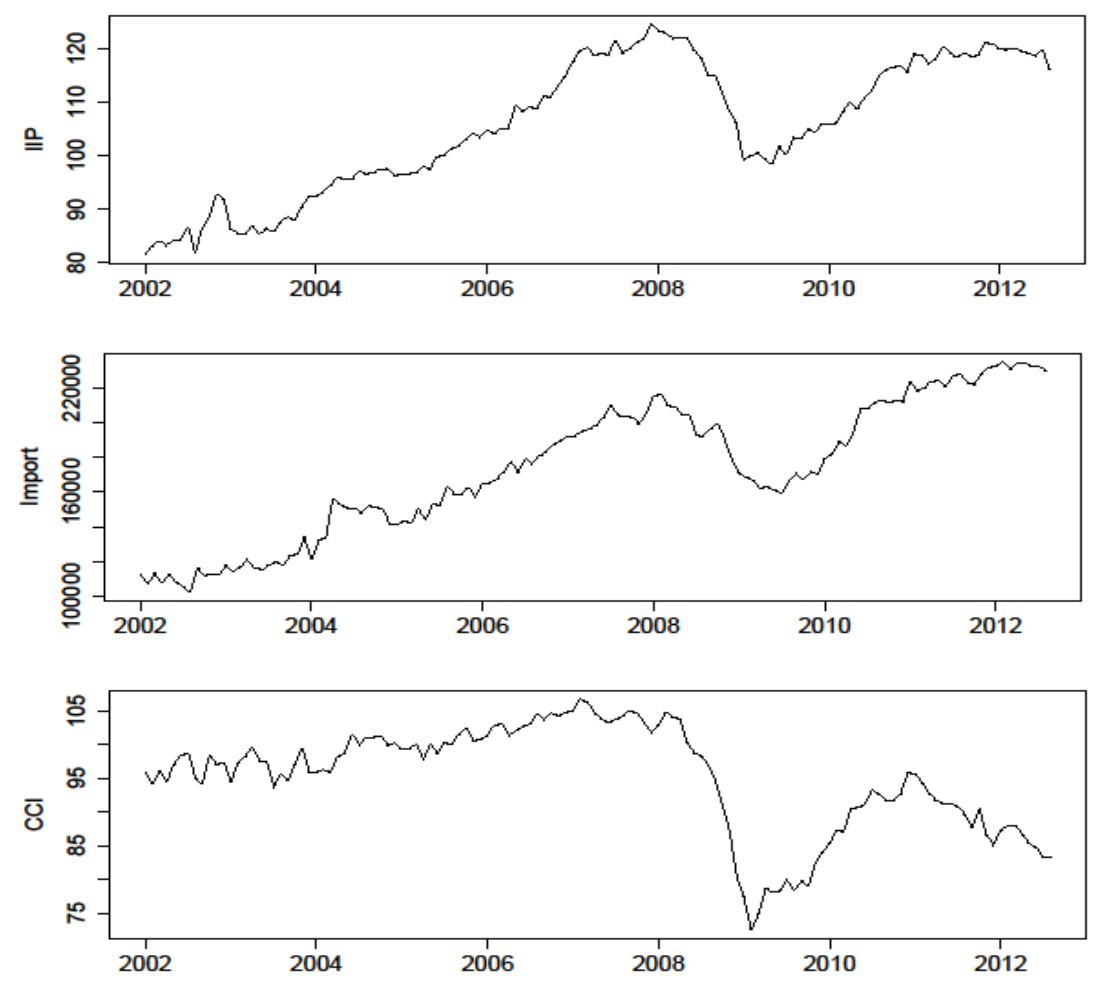

Figure 1 Index of industrial production $(\%$, year $2005=100 \%$ ), import (mil. CZK) and composite confidence indicator $(\%$, year $2005=100 \%)$ from January 2002 to August 2012. Data source: Czech Statistical Office.

Although the time series were seasonally adjusted, they still had to be decomposed by Hodrick-Prescott filter and their trend component had to be removed. The Hodrick-Prescott filter was applied twice to obtain smooth cycle component.

\subsection{Cycle Chronology}

Over the period from January 2002 to August 2012 the Bry-Boschan algorithm found three cycles measured from peak to peak in IIP and CCI time series (see fig. 2). The import cycle is missing the first peak which had to occur before January 2002. It can be assumed, that import skipped the first cycle as its other peaks and troughs usually follow the peaks and troughs of the reference time series.

The average length of the cycle phase is 17.3 months for IIP, 20.2 months for import and 17.2 months for CCI. The discrepancy between the cycle lengths is caused mainly by the delay of the last peak of the import indicator. When working with growth cycles, the phase of expansion is usually longer than the phase of the contraction. This is obvious also in our data: the average duration of the expansion phase is $22.7,24.3$ and 21.7 months and the average duration of the contraction phase is 12.0, 14.0 and 12.7 months for IIP, import and CCI, respectively. 

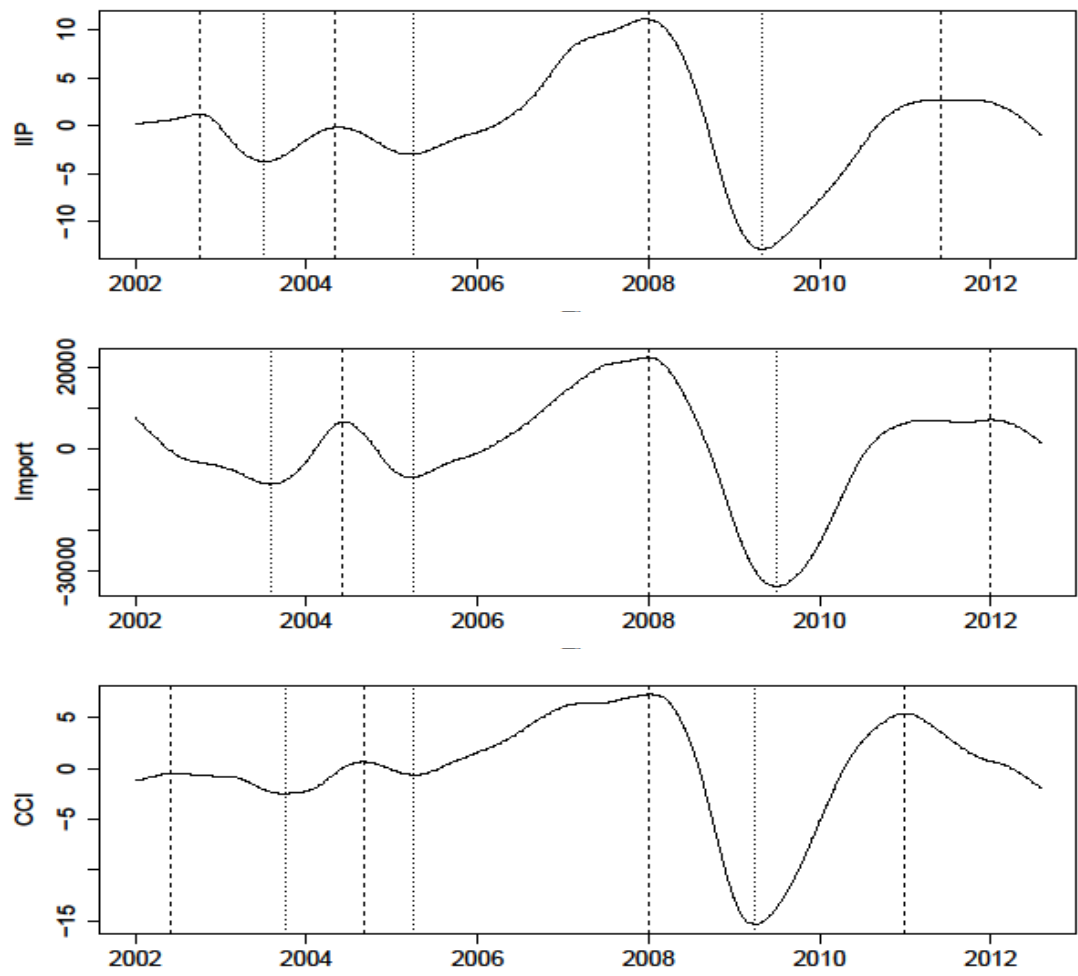

Figure 2 Cycle component of index of industrial production, import and composite confidence indicator from January 2002 to August 2012 with emphasized peaks and troughs, which were detected by Bry-Boschan algorithm.

Import and CCI don't miss any turning points (except the first peak of the import cycle) and have no extra turning points either when compared with the reference time series. The average lag of the import turning points is equal to 1.8 months and the average lead of the CCI turning points is equal to 0.4 months (table 1 ).

Table 1 Dates of the cycle turning points of index of industrial production, import and composite confidence indicator and leads (-), coincidences $(0)$ and lags $(+)$ in months relative to IIP cycle turns.

\begin{tabular}{crrrrr}
\hline \multirow{2}{*}{ Peak/Trough } & \multicolumn{3}{c}{ Turning point dates } & \multicolumn{3}{c}{$\begin{array}{c}\text { Leads, coincidences } \\
\text { and lags }\end{array}$} \\
\cline { 2 - 6 } & IIP & \multicolumn{1}{c}{ Import } & CCI & Import & CCI \\
\cline { 2 - 6 } P & Oct-02 & - & Jun-02 & - & -4 \\
T & Jul-03 & Aug-03 & Oct-03 & +1 & +3 \\
P & May-04 & Jun-04 & Sep-04 & +1 & +4 \\
T & Apr-05 & Apr-05 & Apr-05 & 0 & 0 \\
P & Jan-08 & Jan-08 & Jan-08 & 0 & 0 \\
T & May-09 & Jul-09 & Apr-09 & +2 & -1 \\
P & Jun-11 & Jan-12 & Jan-11 & +7 & -5 \\
\hline
\end{tabular}


The import turning points usually follow the IIP turning points which would classify import as one of the lagging indicators. The lagging indicators are used to certify the cycle behavior and the dating of the turning points. The average lag of the import turning points is 1.8 months. However, the lag time is rather unstable (from 0 to 7 months).

The behavior of the CCI turning points is even more erratic. Its turning points appear sometimes in the lead of the IIP (up to 5 months in 2011) and sometimes are lagged (up to 4 month in 2004). The average lead of the turning points is 0.4 months which would classify CCI most likely as the coincident indicator.

All the indicators had coincident trough in April 2005 and coincident peak in January 2008. The long slowdown that followed after January 2008 can be linked to the global financial crisis. This slowdown ended after more than one year in May 2009 (considering IIP series).

\section{Cross correlations}

Cross correlations analysis is other method that can be used to determine the relationship between the reference series and the individual economic indicator in the evaluation phase of the OECD methodology, which was mentioned above. Cross correlations measure the linear dependency between the reference series and individual indicator with applied time-lag. Then the maximum of absolute value of cross correlation is found and the individual indicator can be included into one of the composite indicators (leading, coincident or lagging) according to the time-lag where the maximal value appeared.

The advantage of cross correlation is that they are easy to compute and that their results can be quickly evaluated. However, cross correlations measure only general fit between individual indicators and the reference time series. The goal of the composite indicators is nevertheless to predict the turning points of the reference time series (when will the economy switch from the expansion phase into the contraction phase or vice versa) not to forecast the level of economy. This can cause problems, because the indicators can show strong linear dependency on the reference time series and still miss some of the cycles, contain extra cycles or the lead (lag) time of their turning points can significantly fluctuate.

Table 2 Cross correlations of cycle components of import and composite confidence indicator compared to cycle of index of industrial production with applied time-lag.

\begin{tabular}{lccccccccccc}
\hline & $\mathrm{t}-5$ & $\mathrm{t}-4$ & $\mathrm{t}-3$ & $\mathrm{t}-2$ & $\mathrm{t}-1$ & $\mathrm{t}$ & $\mathrm{t}+1$ & $\mathrm{t}+2$ & $\mathrm{t}+3$ & $\mathrm{t}+4$ & $\mathrm{t}+5$ \\
\hline Import & 0,6611 & 0,7301 & 0,7880 & 0,8467 & 0,8864 & $\mathbf{0 , 9 1 6 9}$ & 0,9012 & 0,8904 & 0,8517 & 0,7950 & 0,7258 \\
CCI & 0,7602 & 0,8101 & 0,8417 & 0,8689 & $\mathbf{0 , 8 7 9 7}$ & 0,8596 & 0,8205 & 0,7570 & 0,6854 & 0,6001 & 0,4985 \\
\hline
\end{tabular}

If import and CCI would be evaluated based on cross correlations only (see table 2), import would be classified as one of the coincident indicators and CCI as the leading one. Both of them show strong linear relationship with the reference time series and they would be probably included in the composite indicators.

However, the analysis of the turning points suggests that import is more likely the lagging indicator and that CCI behaves as the coincidence indicator. Import is also missing the first peak and the lead (lag) times of import and CCI turning points aren't quite stable. 
The decision, whether to include import and CCI to the composite indicators or not, based on these insights wouldn't be so clear.

\section{Conclusion}

This paper focused on the evaluation phase of the OECD methodology of composite indicators construction. In this phase cycle components of all evaluated individual indicators are compared to the reference series. Their relationship can be described by several methods: the average lead (lag) times between the turning points, cross correlations and number of extra and missing cycles. The selected individual indicators are then divided into groups of leading, coincident and lagging ones and the composite indicators are created.

In the Czech Republic it has become common practice to use only cross correlations to test the relationship between individual indicators and the reference series. This paper compared results of the cross correlation analysis with the Bry-Boschan algorithm for tracking the turning points of the cycle component. It has proved that cross correlations gave different results than the turning points analysis and also provided less information about the relationship between the reference series and individual indicators.

Author would recommend using cross correlations as a pre-selection method - to reduce the number of the individual indicators, which turning points would be then tracked and analyzed.

\section{References}

1. Bruno, G., \& Otranto, E. (2008). Models to date the business cycle: The Italian case. Economic Modelling 25(5), 899-911.

2. Bry, G., \& Boschan, C. (1971). Cyclical analysis of time series: selected procedures and computer programs. National Bureau of Economic Research, 216.

3. Czech Statistical Office. (2012). Business cycle surveys - Methodology. Retrieved 5 25, 2013, from http://www.czso.cz/eng/redakce.nsf/i/business_cycle_surveys

4. Czesaný, S., \& Jeřábková, Z. (2009). Kompozitní indikátory hospodářského cyklu české ekonomiky. Statistika(3), 256-274.

5. Gyomai, G., \& Guidetti, E. (2012). OECD System of Composite Leading Indicators. OECD Publishing, 18.

6. Levanon, G. (2010). Evaluating and comparing leading and coincident economic indicators. Business Economics, 45(1), 16-27.

7. Nilsson, R., \& Gyomai, G. (2011). Cycle extraction: A comparison of the Phase-Average Trend method, the Hodrick-Prescott and Christiano-Fitzgerald filters. OECD Publishing, 23.

8. Ozyildirim, A., Schaitkin, B., \& Zarnowitz, V. (2010). Business cycles in the euro area defined with coincident economic indicators and predicted with leading economic indicators. Journal of Forecasting, 29(1-2), 6-28.

9. Ravn, M., \& Uhlig, H. (2002). On adjusting the Hodrick-Prescott filter for the frequency of observations. Review of Economics and Statistics, 84(2), 371-376.

10. Tkáčová, A. (2012). Kompozitný predstihový indikátor hospodárskeho cyklu českej ekonomiky. Politická ekonomie(5), 590-611.

11. Zarnowitz, V., \& Ozyildirim, A. (2006). Time series decomposition and measurement of business cycles, trends and growth cycles. Journal of Monetary Economics, 53(7), 1717-1739. 